\title{
Health Professionals Training: Strategies of Sensibility to Work with the Community
}

\author{
Marta Fuentes-Rojas \\ School of Applied Sciences, University of Campinas ,UNICAMP Limeira-SP ,Brazil
}

\begin{abstract}
This article reports a classroom experience with Sports Science and Nutrition students. The objective was to characterize the field of public health, as a process of collective building and production space of knowledge, practices, promoting a theoretical and critical reflection in relation to different educational practices used in health education. Employing different methodological strategies that not only overcome resistance to the contents, but also stimulate the students to work with communities. Experience has shown that differentiated teaching and learning processes represent more difficulty, because they demand more dedication and responsibility from both the teacher and the students, confirming the importance of searching through more interactive activities: It leads to students development as professionals and citizens.
\end{abstract}

Keywords Development Professional, Methodological Strategies, Intervention Projects, Work with Communities

\section{Introduction}

Nowadays, it is clear that students in the classroom have less involvement with the basic contents of the development, while the traditionally used methodologies prove to be increasingly less efficient. As a pro fess or of the health area, specifically instructing Psychology, Public Health, Health Education and Communication in this area, this last two so called "service disciplines" allow me to observe great resistance, lack of interest and motivation, on the part of students to contents related to the collective health, and it expanded to the Psychology course[1], as well. Working with Nutrition and Sports Science students, the strangeness was even more accentuated, besides being an underrated content by the specific development areas.

When faced to real daily problematic situations concerning the health area, the students exercise the practice-theory-practice relation having reality as the starting and departure point of the learning process. It's essential to search for ways to work with different pieces of knowledge, to look at each person respecting his background and not considering ourselves as the only ones mastering all the knowledge.

The aim of these disciplines was to promote a theoretical and critical thinking related to the Public Health as a collective building space and the different educational practices used in health, as well as promoting the practice of pedagogical didactic methodologies as support tools for

* Corresponding author:

marta. fuentes@fca.unicamp.br (Marta Fuentes-Rojas)

Published online at http://journal.sapub.org/phr

Copyright (C) 2012 Scientific \& Academic Publishing. All Rights Reserved research and intervention.

Therefore, it presents the classroom experience with the Public Health, Health Education and Communication disciplines, using different methodological strategies to overcome resistance to the contents, and to stimulate students to work with communities.

\section{Transformer Education}

To think of education as transformer of practices and knowledge requires commitment from the educator and his student. Education needs to move toward allowing and facilitating the growth of human beings who respect themselves and others; so that they can act with responsibility and freedom[2]. To be able to act and reflect, the student needs to be aware and conscious of his presence in the world and to appropriate it and "to know himself in it" (p.16)[3].

The human being has a natural potential to learn, i.e., requires adequate resources and space to take ownership of their learn ing[4]. According to Freire, one cannot think about education without considering the man himself in a constant constructing state, because he "knows himself and recognizes that he is unfin ished"[3],[5]. Education implies a search for the subject of your own education. "[...] so nobody educates anybody, but no one is self educated, men educate thems elves, each other, mediated by the world." (P.28),[3]

In this context of learning, content although significant, is in the background and success does not happen when the student learns everything he had to learn, but when he learns how to learn what he wants to know[4],[6],[7].

The educator as facilitator trusts the student, shares responsibility for the learning process, provides resources 
inherent not only from his attitude and experience, but also fro $m$ the material and the systematic knowledge[4],[3].

Accepting the student "as a valid being in the present, by correcting his doings not his being. The respect for each other, a loving demeanor towards him will only occur if we see him and by seeing, accept him in his legitimacy "(p.26)[2].

Education despite some movements remains vertical, because the teacher is still a higher being and the student passively receives the knowledge, becoming the educator's depository. The teacher retains knowledge as being unique and does not seek new information, because it is not challenged by the students [5],[3],[8]. In this traditional view, it is thought that the more you give, the more you know, at the creativity's expense.

For all this, education must bring the student to reflect on their context, not as a mere spectator of reality, but as a subject. Therefore, he needs spaces that will provide alternatives for the development of skills and potentials, enabling the intervention and the opportunity of being, of thinking and of acting, in other words, to be education's subject, not its instrument.

The new educational proposals are for an eminently problem-based education, mainly critical, reflective and transformative that does not stop in the discourse, but that requires action. The new models promote the exchange, changing already established schemes, creating discomfort for the student and the teacher; it is easier to offer what is already available, than dispose to create new information through the dialogue and acceptance of the other's knowledge; moreover to be open to challenges regarding their own practice.

The professional training must go beyond technique, it needs to prepare professionals with a wide backg round, with an investigative thinking that can identify and handle the market and the social demands involved in their profession and their upbringing as a person.

\section{Reflecting the Practice}

Through the experience in the classroom, the exchange, the reflection and the dialogue, the criticism often overwhelming while rich by the students, helped build a critical view of the practice as a teacher. In this sense, the assessment present in the making becomes a supportive tool and generates in the educator the possibility of having an opening in the building of the most appropriate methodologies for the group that demands your performance.

In relation to what we call "methodological strategies," the way to address the contents does not match the dynamics for me rely motivating students or simp ly bringing the mc loser to each other, but rather, creating activities whose primary purpose is the development of skills, of inquiring thinking, creating true emotional bonds, the interaction for the achievement of collective tasks, the use of available knowledge, reflections on practice and to evaluate the work done.

By questioning real situations, the student is led to exercise the practice-theory-practice connection, having the reality as the starting and departure point of the learning process.

From this thought, education is in a constant movement of change and growth that never stops; where the established and the new knowledge are in a dynamic connection that leads to the review, the reflection and the creation of new forms of action that monitor the rapid and great advances of mankind.

Innovations bring both positive and negative repercussions, not only by the characteristics and different assumptions of the new ways of teaching and learning, but also by the natural resistance to change[9].

The previously mentioned led us to reflect on the class roome xperience, of disciplines that discuss new and not specific contents of the field of study. The fact that they are mandatory and not part of the specific contents of the nutritionists and sports scientists, promoting more resistance and devaluation by the professionals of different areas, as well as the students themselves, led to the search for new forms of action in these disciplines, and to identify the need to offer tools for the development of skills and competencies for health work.

The objective was to advocate a theoretical and critical reflection regarding the Public Health as an area of construction, and the different practices used in health education, at the same time, to promote the use of didactic and pedagogical methodologies as support tools for the work with the community.

We believe that in planning a course, the choice of a methodology requires the consideration of some points such as: to whom we are planning this lesson, what events have already been experienced in the approach and motivation of these students, what are their training needs and what changes can be promoted in them and their social environment.

\section{Methodology}

The courses were developed in two semesters; the first approached the Public Health and the second, Health Education and Communication Course.

The subjects worked in Public Health have been developed using different methodological techniques such as: Theoretical classes, group works, participant observation (field knowledge and diagnosis of health needs), directed studies, integration dynamics, seminars, debates, reading assignments (compulsory and complementary), among others.

There were discussions of the following subjects:

- The health-disease process. For the discussion in addition to reading the texts, the students were required to perform a survey among the population; in order to contrast 
the popular with the systematized knowledge. The chosen slogan was "what they mean by health and disease."

- The discussion of the "We as health professionals" paradigm, sought to reflect on the nutritionists and sports scientis ts role in the field of Public Health.

- In the field work, was discussed the participating observation theme, and an observation and interview itinerary was provided, which would help them in the field work.

- Among other topics: the concept of health; the health lectures and letters; the promotion and prevention concepts, health demands and needs; the Unified Health System (Sistema Único de Saúde) SUS; the public health primary care; the Family Health Strategy - ESF; humanization and health care; care as value; subject dimensions and comprehensiveness of care; interdisciplinary field; team work; public policies and the public health field as a collective process of construction and space for knowledge production and practices[10].

At the end of the Public Health course, a "neighborhood fair" was conducted with the purpose of socializing the observation experiences, and to know the demands and needs present in the population. The written paper was a scientific report of the visit, and the elaboration of an intervention project to be developed during the Health Education and Communication course

At the first class meeting of this discipline, the field work was summarized and all the guidelines were provided, regarding the intervention project as the central work for the Health Education and Communication discipline. The following group work techniques were presented and experienced: workshops, group dynamics, discussion groups, experiment reports, wheel method[11] and the "problemat ic methodology"[9], among others, in order to understand each technique development process and to decide which ones would be used in the community activities.

Among the topics discussed in this course are:

- Definition of educator, of education and of health education in order to confront the students knowledge with the systematic. The educator's posture and his social role.

- Health education in Brazil, basic concepts, limits and possibilities, fields of action and as a practice in primary care, which focuses on health promotion and prevention.

- Pedagogical models and approaches used in health care.

- Concepts of community, commun ity education, popular participation, in order to stimulate the students to work with the community.

The intervention project has been enhanced, in parallel with the different concepts discussion, and was chosen: the theme, the target population, the goals and the necessary actions to achieve it.

During the projects development, under the teacher's supervision, several presentations were made, to discuss the actions and to suggest changes.

To present the results at the end of the course, there was a workshop denominated "experiences exchange", with the goal of evaluating the experience and identifying strengths and weaknesses, and to discuss strategies for the practice optimiztion in the classroom.

There were on average 50 students per discipline, each with $15 / 4$ hours meetings, with a total of 60 hours load.

\section{Results and Discussion}

In the first day, we were faced with the fact that $92 \%$ (46) of students enrolled in the discipline, were from the Sports Science course and only $8 \%$ (4) were from the Nutrition. Is important to clarify what this course is offered in two classes with different teachers. A more balanced student distribution between the two courses was expected, but it did not happen.

In Public Health were presented and discussed the disciplines fundamental concepts. Different authors were brought in for discourses on health as a collective building and space for promotion and prevention among the population. Activities were directed to the theoretical discussions and the preparations for the field observation.

Earlier, students had difficulty understanding the need for the observation, complained about the distance between the neighborhoods and the school questioned the observation guidelines, and particularly, the Public Health importance in Sports Science students. It was clear that students in this area have difficulty in seeing themselves as public health professionals.

During 15 meetings, with a 4 hours load, there were classroom discussions of the theoretical concepts; the last minutes of seven meetings were dedicated to the field observation planning (districts in the city of Limeira - SP). Twelve districts were chosen and distributed according to their locations, aiming to reach the city different sectors (downtown, suburbs and/or different social strata). The students were divided into 5-6 students groups. For this activity an observation itinerary was provided as well as interview samples for the residents, the merchants, the health professionals, the community leaders, among others.

The observation experience allowed the students to develop skills for approaching the residents and the professionals from different sectors, and to understand that every situation experienced in the neighborhoods, somehow interferes with the populations health. They understood the importance of each sector within the neighborhood, and the attention to the health care and the education by area of scope.

At the end of the course, there was a "Neighborhood Fair" in an open area of the school grounds. Each group was creative in their presentations, answered questions and identified the health needs of the population visited.

From the observation and presentation they were able to understand in practice, the discussions made in the classroom. According to statements by some students,

"[...] gave meaning to public health;" "during the neighborhood visit and in the presentation, I realized the importance of public health and our role as health professionals." "Learning to identify the neighborhoods needs was very motivating." "In the neighborhoods 
presentation, we realize that the people's needs are similar, and that together we can come up with solution strategies."

In the Health Education and Communication first day of class, after retrieving the Public Health work, we were faced with the fact that 21 of the students enrolled, had not attended the observation activity during the previous semester; thus requiring some adjustments and changes in the final work planning.

Among the strategies, the students were required to perform field work, to make a general presentation of their experiences in the neighborhoods and a survey of the population needs. Another strategic requirement was for the groups to have students from both courses, but there were some challenges and unwillingness to work together as a group. Nevertheless, during the class room discussions, they showed great interest in contributing to improve the activities of the different groups. Some groups chose to develop the work in the visited communities; while others sought institutions to perform the work.

After overcoming various difficulties, it was decided by the group to work with a specific theme in all co mmunities or locations chosen. The chosen theme was: "Garbage," for being a real problem in all the different places visited. As this was a theoretical and practical discipline, the focus of discussions and experiences of the techniques were around the theme and the activities preparation for the work with the population.

The Alforja [12] team, states that the techniques are tools in the tra ining process, seeking to create and recreate. But the key is not the use of participatory techniques alone, without the methodology concept that guides the process, which is based on the knowledge construction. This means they say, from the practical $v$ iew, i.e., what the population knows, lives and feels in the different situations they face in their daily lives, that was the focus of the intervention projects.

Participatory techniques, to really promote a learning process, should allow both a collective discussion and a reflection. They enable the individual and collective knowledge to be enriched and potentialized from common points. The participants bring their individual knowledge; thus enriching and enlarging the collective experience. [5],[12],[2],[13],[14].

The activities to be held in the community were first experienced in the classroom, and changes made where it was necessary. The projects were presented at various times, and collectively discussed and agreed upon before going into the field. This allowed the collective creation of knowledge, where all were participants of the development and of the practical implications. The objective was to sensitize the students, to learn about what the people already own and what was brought by the group.

The project's development process demanded from the students various activities including: site search, target population identification, contacts, project presentation and request for authorization from the site's coordinator or director, preparation of workshops and materials, group organization for the tasks distribution, the projects theoretical foundation, supervisory involvement, as well as coping with the population motivation and concentration to develop the project.

This move, to a certain extent, led to the attitudes, students need to develop when planning to work with education. Maturana and Nisis [3], predicate that the educative process is intended to guide our students in their upbringing as human beings who respect themselves and others, in a continuous configuration of a living space that promotes and makes the collective construction possible, an investigative thinking and fulfilment wish, developing responsibility attitudes, collaboration, joy and freedom to Be, Think and Do.

During the development of the discipline it was emphasized the education contribution, to the development of health actions that transform people's habits through the knowledge of the everyday and the population demands. Still, it was difficult for the students to understand that health education is part of a wider context that goes beyond the population's shift to healthier habits.

In education it is important not only to overcome the individuals' resistance, but also to encourage them to actively participate, through his knowledge and their circumstances [15]. At the same time we must recognize their knowledge[3], which causes them either improve their health or damage it. This recognition lies in the ethical principle of the respect for individual liberty[2],[4],[5],[14][16],[17].

With this view, the students visited the neighborhoods in advance for a first contact with the reality and with the people in the community.

The intervention projects were performed by 11 groups, with 2 to 7 members. It was possible to return to five (5) of the neighborhoods previously visited in the Public Health discipline. The remaining groups made contact with educational institutions to develop the project. The meetings with the population were on average, 3-4 per project.

The visited sites were: elementary schools (public and private), orphanage, community centers, training center for the mentally disabled, city central square and municipal day care. The target audience: ch ild ren, adolescents with learning disabilities and the general population (in the square).

All projects were aimed to educate the target population in relation to the proper management of garbage, recycling and hygiene, through fun activities and the building of toys using recycled material.

The practice of these activities and the planning of the intervention project, allowed the students to realize that when considering the other's freedom and autonomy; one cannot change people's habits devoid of the understanding of their reality and without their participation. According to Guenther[18], the world view is one factor that influences the perception and everyday experiences, which leads people to interpret and select what to include or ignore according to their perceptions.

In the classroom practical activities, the students had difficulty working with different methodologies, which demanded greater involvement, reflection and creativity. At 
the beginning they proved to be apathetic, resistant and had difficulty understanding the collective construction process. Toward the end of the meetings, despite the lack of involvement in some activities, there were improved integration among them; they have become more participatory, critical, problematic and supportive. And the contact with the community brought about changes in attitudes toward the disciplines contents and the insights about the community.

This experience has allowed us to realize that the concepts can be worked in different ways, and it is necessary to provide enabling tools for the development of skills and the concepts construction through the theory - practice relation.

Here are some of the groups' manifestations in relation to work with the commun ity:

"[...] Had some good results, even with difficulties[...] were able to hold the people's interest and they really liked to learn and build objects" (G9), "we could see changes in the children's behavior, from the first to the last meeting,[...] going beyond our expectations "(G2).

As for the project's contributions to the group members:[...] "after the experience lived in recent weeks, the group realized how rewarding it can be to participate in a project like this, not only because the children accepted the teachings quickly [...], but also, they were very grateful "(G3); "The project was tiring, however, very rewarding ... "(G1); "[...] was very useful, because it provided contact with a different audience[...] willing to learn" (G4).

"The group was pleased with the opportunity to return to the same neighborhood visited last semester. We noticed that it does not matter if we have a good design on paper, there is great difficulty for the spaces to open the doors, and often, what we plan cannot be realized in practice "(G7).

In "experiences exchange" students presented their productions through film, photographs, newsletters, brochures in addition to toys and utensils made from recyclable material. They demonstrated responsibility before the communities, and care in the workshops' organization and preparation.

In the course's evaluation, the students pointed out the strengths, the weaknesses and made some improvement suggestions. Here are the considered strengths: going from visualization to practice through the proposed methodology; putting into practice the discipline concepts; new knowledge and learning through projects outside the classroom; departing from the classroom routine; learning to create intervention projects; dealing with the problems and challenges that arose during the activities; contrasting the same projects different approaches; counting on everybody's participation according to the integration dynamics within the classroom; learning to cope with different social contexts; not only in exchanging experiences both in the classroom and with the community, but also learning to evaluate each other's work, which led to the work commitment.

Among the weaknesses were: difficulties in organizing the projects schedule; only one project of the kind for the four (4) years of college limitation; difficulties in the interaction of the two courses (Sports Science and Nutrition); the lack of experience in the neighborhoods observation (for the students new to the assignment); short time available for the activities; disinterest by some of the students.

Among the suggestions for improving the discipline development were the following: mandatory participation in field work (field knowledge); project development throughout the semester; requirement for the groups to develop with at least two age groups, to experience different challenges and solutions in the same project.

\section{Conclusions}

Despite of the difficulties encountered, such as, large numbers of students, low interest and appreciation for the Public Health field, resistance to new strategies requiring greater involvement, dedication and responsibility from both the student and the teacher, the community intervention and change in attitudes by some students, confirm the importance of searching, through more participatory activities, for the meaning of their formation as professionals and citizens.

To offer students the opportunity to get in touch with reality and from it to identify situations that give meaning to their training becomes undeniably rich and challenging.

We recognize that the methodologies require some improvement; however, as an experience, it invites us to review the Public Health strengths and weaknesses and to give continuity to its work proposal.

In the training of health professionals becomes necessary to offer an opportunity to be more active, critical; with a world view that contributes to the collective construction of knowledge, and to practice in a more human manner, besides the willingness to work interdisciplinary.

\section{ACKNOWLEDGEMENTS}

Students of Nutrition and Sport Sciences who attended the course in 2010 and 2011, as well as the people that allowed the development of the projects.

\section{REFERENCES}

[1] M. Fuentes-Rojas. "Psicologia e Saúde: A terapia comunitária como instrumento de sensibilização para o trabalho com comunidades na formação do psicologo" Psicologia: Ciência e Profissão, vol. 31, no.2, pp. 420-435, 2011.

[2] H. Maturana, S. de R. Nisis. "Formación humana y capacitación”, UNICEF-Chile / DOLMEN ediciones, 1997.

[3] P. Freire. "Educação e mudança”, Rio de Janeiro: Paz e Terra, Coleção Educação e Comunicação, vol.1. 29a. ed ição. 2006.

[4] C. Rogers. "Liberdade de aprender em nossa década", Porto Alegre, Artes médicas, 2a. edição, 1986.

[5] P. Freire. "Pedagogia da Autonomia: Saberes necessários à 
prática educativa”, São Paulo - SP, Paz e Terra, 7a. Edição, 1998.

[6] J. D. Bordenabe; A. M. Pereira. "Estratégias de ensino-aprendizagem”, Petrópolis, Vozes, 15a. Edição, 1995.

[7] J. R. Doxsey. “Aprendizagem e educação centrada na pessoa: o desafio da síntese de seus princípios”, F. C. de S. Klöckner (org.) Abordagem centrada na pessoa: a psicologia humanista em diferentes contextos. Londrina: EdUniFil. 2009.

[8] C. Rogers. "Sobre o poder pessoal". São Paulo: Martins Fontes, 4a. ed. 2001.

[9] N. A . N. Berbel. "A problematização e a aprendizagem baseada em problemas: diferentes termos ou diferentes caminhos?", Interface. Botucatu, vol.2, no.2. 1998. OEI $<$ http ://www.scielo.br/scielo.php?script=sci arttext\&pid=S1 414-32831998000100008\&lng $=$ en\&nrm $=$ iso $>$. [Consulta:nov. 2004].

[10] G. W. de S. Campos. "Clinica e Saúde Coletiva compartilhadas: teoria PAIDÉIA e reformulação ampliada do trabalho em saúde, G.W.de S. Campos (et.al), Tratado de Saúde Coletiva, São Paulo: Hucitec, Rio de Janeiro:Ed. Fiocruz, pp. 53-92, 2006.

[11] G. W. de S. Campos. “Um métodopara análise e co-gestão de coletivos: a constituição do sujeito, a produção de valor de uso e a democracia em instituições: o método da roda”. São Paulo: Hucitec. 2000.

[12] Alforja (Equipe). "Técnicas participativas para la educación popular". Publicaciones de Educación Popular. Buenos Aires, Argentina. LUMEM-HVMANITAS-CEDEPO. $7^{\mathrm{a}}$.Edición. 1996.

[13] J. L. Ferreira Neto, et al. "Usos da noção de subjetividade no campo da Saúde Coletiva”. Cad. Saúde Pública, Rio de
Janeiro, v. 27, n.5, maio 2011. Disponível em $<$ http ://www.scielo.br/scielo.php?script=sci arttext\&pid=S0 102-311X2011000500002\&lng=pt\&nrm=iso $>$. Acessos em 14 maio. 2012 http://dx.doi.org/10.1590/S0102-311X201100 0500002 .

[14] L. B. Gomes; E. E. Merhy. "Compreendendo a educação popular em saúde: um estudo na literatura brasileira". Cad. Saúde Pública, Rio de Janeiro, v.27, n.1, jan. 2011. Disponível em $<$ http://www.scielo.br/scielo.php?script=sci arttext\&pid=S0102-311X2011000100002\&lng $=$ pt\&nrm $=$ iso >. acessos em 24 maio 2012.. http://dx.doi.org/10.1590/S010 2-311X2011000100002.

[15] R. Biceño-León. "Siete tesis sobre la educación sanitaria para la participación comunitaria”. Cadernos de Saúde Pública. Rio de Janeiro. 12(1):7-30. jan-mar. 1996. OEI $<\mathrm{http}: / /$ www.scielo.br/scielo.php?script=sci_arttext\&pid=S0 102-311X1996000100002\&lng $=$ en\&nrm=iso $>$. [Consulta: agosto de 2001].

[16] K. C. B. M. Diogenes; M. Nations. ""Prismas de percepção": múltiplas leituras das campanhas em saúde no Nordeste brasileiro". Cad. Saúde Pública, Rio de Janeiro, v. 27, n. 12 dez. 2011. Disponível em <http://www.scielo.br/scielo.php?s cript $=$ sci_arttext\&pid=S0102-311X2011001200018\&lng $=\mathrm{pt}$ $\& n r m=i s{ }^{-}>$. acesso em 14 maio. 2012. http://dx.doi.org/10.1 590/S0102-311X2011001200018.

[17] A. Matinez-Hernaez. "Dialógica, etnografia e educação em saúde”. Rev. Saúde Pública, São Paulo, v. 44, n. 3, jun. 2010. Disponível em <http://www.scielo.br/scielo.php?script=sci_ arttext\&pid $=$ S0034-89102010000300003\&lng=pt\&nrm $=$ iso $>$. acessos em 25 mar. 2012. Epub 21-Maio-2010. http://dx.doi.org/10.1590/S0034-89102010005000016.

[18] Z. C. Guenther. "Educando o Ser Humano: Uma abordagem da psicologia humanista", Campinas-SP: Mercado de Letras, lavras, MG: Universidade Federal de Lavras. 1997. 